Research Article

\title{
Chronic Hepatitis C Virus Infection Modulates the Transcriptional Profiles of $\mathrm{CD4}^{+} \mathrm{T}$ Cells
}

\author{
Michal Holub $\mathbb{D}^{1},{ }^{1}$ Alžběta Stráníková, ${ }^{1}$ Ondřej Beran, ${ }^{1}$ Simona Arientová, ${ }^{1}$ \\ Oldřich Bartoš, ${ }^{1,2}$ Kateřina Kondelková, ${ }^{3}$ Stanislav Plíšek, ${ }^{4}$ and Pavel Chalupa ${ }^{5}$ \\ ${ }^{1}$ Department of Infectious Diseases, First Faculty of Medicine, Charles University and Military University Hospital Prague, \\ U Vojenské Nemocnice 1200, Praha 6169 02, Czech Republic \\ ${ }^{2}$ Institute of Animal Physiology and Genetics, Laboratory of Fish Genetics, Czech Academy of Sciences, Liběchov, Czech Republic \\ ${ }^{3}$ Institute of Clinical Immunology, Faculty of Medicine in Hradec Králové, Charles University, Sokolská 581, \\ Hradec Králové 500 05, Czech Republic \\ ${ }^{4}$ Department of Infectious Diseases, Faculty of Medicine, Charles University and University Hospital, Sokolská 581, \\ Hradec Králové 500 05, Czech Republic \\ ${ }^{5}$ Department of Infectious and Tropical Diseases, First Faculty of Medicine, Charles University and University Hospital Bulovka, \\ Budinova 2, Praha 8180 81, Czech Republic
}

Correspondence should be addressed to Michal Holub; michal.holub@lf1.cuni.cz

Received 3 December 2020; Revised 16 February 2021; Accepted 4 March 2021; Published 12 March 2021

Academic Editor: Aseer Manilal

Copyright $\left({ }_{0} 2021\right.$ Michal Holub et al. This is an open access article distributed under the Creative Commons Attribution License, which permits unrestricted use, distribution, and reproduction in any medium, provided the original work is properly cited.

Background. Chronic hepatitis $\mathrm{C}(\mathrm{CHC})$ is associated with altered cell-mediated immune response. Objective. The aim of the study was to characterize functional alterations in $\mathrm{CD}^{+} \mathrm{T}$ cell subsets and myeloid-derived suppressor cells (MDSCs) during chronic hepatitis $\mathrm{C}$ virus (HCV) infection. Methodology. The expression levels of the lineage-defining transcriptional factors (TFs) T-bet, Gata3, Ror $\gamma t$, and Foxp3 in circulating CD4 ${ }^{+}$T cells and percentages of MDSCs in peripheral blood were evaluated in 33 patients with CHC, 31 persons, who had spontaneously cleared the HCV infection, and 30 healthy subjects. Analysis. The CD4+ T cells TFs T-bet (T-box expressed in T cells), Foxp3 (Forkhead box P3 transcription factor), Gata3 (Gata-binding protein 3), and Ror $\gamma \mathrm{t}$ (retinoic-acid-related orphan receptor gamma) and activation of CD8+ T cells, as well as percentages of MDSCs, were measured by multicolor flow cytometry after intracellular and surface staining of peripheral blood mononuclear cells with fluorescent monoclonal antibodies. Result. The patients with $\mathrm{CHC}$ had significantly lower percentages of $\mathrm{CD} 4^{+} \mathrm{T}$ cells expressing Ror $\gamma \mathrm{t}$ and Gata3 and higher percentages of Foxp3-expressing $\mathrm{CD} 4^{+} \mathrm{T}$ cells than healthy controls and persons who spontaneously cleared $\mathrm{HCV}$ infection. The ratios of T-bet ${ }^{+} / \mathrm{Gata}^{+}$and Foxp $3^{+} /$Ror $\gamma \mathrm{t}^{+} \mathrm{CD}^{+} \mathrm{T}$ cells were the highest in the patients with $\mathrm{CHC}$. In the patients with CHC, the percentages of $\mathrm{Gata}^{+}$and Ror $\gamma \mathrm{t}^{+} \mathrm{CD} 4^{+} \mathrm{T}$ cells and the percentages of T-bet ${ }^{+} \mathrm{CD} 4^{+} \mathrm{T}$ cells and $\mathrm{CD} 38^{+} /$ HLA-DR ${ }^{+} \mathrm{CD}^{+}{ }^{+}$T cells demonstrated significant positive correlations. In addition, the percentage of CD38 $8^{+} / \mathrm{HLA}^{-D R^{+}} \mathrm{CD}^{+}$ T cells correlated negatively with the percentage of MDSCs. Conclusion. Chronic HCV infection is associated with downregulation of TFs Gata3 and Ror $\gamma$ t polarizing CD4+ T cells into Th2 and Th17 phenotypes together with upregulation of Foxp 3 responsible for induction of regulatory $\mathrm{T}$ cells suppressing immune response.

\section{Introduction}

Chronic hepatitis $\mathrm{C}(\mathrm{CHC})$ represents a serious health problem. The global prevalence of hepatitis $\mathrm{C}$ virus (HCV) infection was estimated to be 71.1 million viremic infections in 2015, with HCV genotypes 1 and 3 being the most prevalent (44\% and 25\%, respectively). Despite great progress achieved in recent years in the treatment of chronic $\mathrm{HCV}$ infection, $\mathrm{CHC}$ is still associated with many challenges. First, an important proportion of patients with $\mathrm{CHC}$ are from low- and middle-income countries with a dense population and limited access to expensive therapies with direct-acting antivirals (DAAs) that are highly efficient in the treatment of chronic HCV infection [1]. Second, HCV 
infection occurs asymptomatically in almost $85 \%$ of patients, and the diagnosis of $\mathrm{CHC}$ is often delayed, leading to the development of serious complications, including liver cirrhosis and hepatocellular carcinoma [2]. Finally, in developed countries, HCV infection is frequently associated with the use of intravenous drugs, and users are frequently unaware of HCV transmission routes, symptoms of infection, and availability of DAAs [3]. All of these factors support the continued necessity to develop an efficient vaccine, and an enhanced knowledge of immune responses associated with CHC may help in this effort. However, developing a B-lymphocyte-based vaccine is hindered by $\mathrm{HCV}$ diversity, and therefore, T-cell-based vaccines seem to be a good approach [4].

Regarding the T-cell-based vaccine development, understanding of T-cell-mediated immune responses in $\mathrm{CHC}$ is essential [5]. It has been well documented that a subset of $\mathrm{CD} 4^{+}$ $\mathrm{T}$ cells, regulatory $\mathrm{T}$ cells (Tregs), which are responsible for immunologic unresponsiveness, is significantly elevated in the blood and liver of patients with CHC [6, 7]. Conversely, another subset of $\mathrm{CD}^{+} \mathrm{T}$ cells, interleukin- (IL-) 17-producing $\mathrm{CD}^{+} \mathrm{T}$ (Th17) cells, is associated with spontaneous clearance of acute HCV infection [8]. Similarly, the clearance of HCV infection can be promoted by a subset of $\mathrm{CD}^{+} \mathrm{T}$ cells, Th1 cells that produce interferon (IFN)- $\gamma$ and IL-2, whereas induction of Th2 cells that produce IL-4, IL-5, IL-10, and IL-13 can lead to viral persistence and development of $\mathrm{CHC}$ [5]. It is well known that the lineage commitment of naive $\mathrm{CD} 4^{+} \mathrm{T}$ cells is regulated by encountered antigens and the cytokine milieu at the time of T-cell receptor engagement [9]. These signals and their combinations are critical for the expression of specific lineagedefining transcription factors (TFs) that are responsible for the polarization of naive $\mathrm{CD} 4^{+}$T cells into Th 1 cells, Th2 cells, Th17 cells, or Tregs. For the shift to the particular $\mathrm{CD} 4^{+} \mathrm{T}$-cell lineage, the expression of a specific master regulator $\mathrm{TF}$ is essential. The TF T-bet (T-box expressed in T cells) regulates the shift of naive CD4+ T cells into Th1 cells, Gata3 (Gatabinding protein 3 ) into Th2 cells, Ror $\gamma \mathrm{t}$ (Retinoic acid-related orphan receptor gamma) into Th17 cells, and Foxp3 (Forkhead box P3 transcription factor) into Tregs [10]. Although Th1 and Th17 responses are advantageous in acute viral infections, it is possible that during chronic infections, such as $\mathrm{CHC}$, these $\mathrm{CD} 4^{+} \mathrm{T}$ cell responses are skewed to $\mathrm{Th} 2$ cells and Tregs, $\mathrm{CD} 4^{+}$ $\mathrm{T}$ cell phenotypes that are less efficient for viral clearance [11]. Moreover, CHC is associated with elevated levels of myeloidderived suppressor cells (MDSCs) and persistent activation of $\mathrm{CD}^{+} \mathrm{T}$ cells $[6,12]$.

Thus, the aim of this study was to analyze the expression of the lineage-defining TFs in circulating $\mathrm{CD}^{+} \mathrm{T}$ cells and the percentages of MDSCs in peripheral blood from patients with chronic genotype $1 \mathrm{HCV}$ infection, persons with spontaneous HCV clearance, and healthy subjects. Additionally, the correlations among these cells and other immunological and virological parameters were evaluated.

\section{Materials and Methods}

2.1. Study Groups. This study was conducted at two departments of infectious diseases of two tertiary-care hospitals between 2013 and 2015. The study was approved by the local ethics committees in Prague (IRB00002721, Etická komise Fakultní nemocnice Bulovka, IRB No. 1, Biomedical) and Hradec Králové (IRB00007431, Etická komise Fakultní nemocnice Hradec Králové, IRB No. 1), and it was performed in compliance with the Helsinki Declaration (1996 revision). All study subjects were enrolled only if they expressed their consent by signing written informed consent.

We enrolled 33 patients with chronic genotype $1 \mathrm{HCV}$ infection who attended the hepatology outpatient clinic of either department. The patients were included in the study only if (1) the chronic HCV infection was confirmed by realtime polymerase chain reaction (RT-PCR), (2) the patients were indicated for the antiviral treatment of $\mathrm{CHC}$, and (3) there was no history of previous therapy of chronic HCV infection. The demographic and clinical data are shown in Table 1. For comparison, $31 \mathrm{HCV}$-seropositive persons, who had spontaneously cleared HCV infection (16 males and 15 females; median age 41.5 years, range 27-69 years), were enrolled. These persons were referred to the hepatology clinic of both departments to rule out $\mathrm{CHC}$ and were included in the study only if (1) HCV RNA in the blood was not detectable and (2) untreated acute HCV infection was documented in their medical records. Normal values of studied parameters were obtained from the control group of $30 \mathrm{HCV}$-seronegative healthy volunteers (17 males and 13 females; median age 32.5 years, range $22-62$ years).

2.2. Laboratory Methods. Peripheral blood was collected in $7.5 \mathrm{~mL}$ S-Monovette tubes with Li-Heparin and $2.0 \mathrm{~mL}$ S-Monovette tubes with K3EDTA (both Sarstedt AG and Co, Nümbrecht, Germany) from each study participant.

Peripheral blood mononuclear cells (PBMCs) for TF expression analyses in $\mathrm{CD}^{+} \mathrm{T}$ cells and MDSC measurements were separated using density gradient centrifugation (Ficoll-Paque Plus, GE Healthcare Bio-Sciences AB, Sweden). The cells were washed two times with an RPMI medium 1640 (Invitrogen, Paisley, UK) and resuspended in the RPMI medium supplemented with $20 \%$ fetal bovine serum (FBS) (PAA Laboratories Gmbh, Cölbe, Germany). Resuspended cells were diluted and divided into aliquots, with $10 \%$ dimethyl sulfoxide (CryoSure-DMSO, WAK-Chemie Medical GmbH, Germany) used as cryopreservative. Cryotubes were placed in a freezing container with isopropanol in a freezer at $-80^{\circ} \mathrm{C}$. Samples were stored in liquid $\mathrm{N}_{2}$ for long-term storage. For the analyses, the cells were carefully thawed in a water bath at $37^{\circ} \mathrm{C}$, washed two times with phosphate-buffered saline (D-PBS, Life Technologies Limited, Paisley, UK), and resuspended in PBS at a concentration of $1 \times 10^{6}$ cells per $\mathrm{mL}$. We used antibodies (CD3 PerCP-Cy5.5, CD4 PE-Cy7, CD8 APC-eFluor 780, Ror $\gamma \mathrm{t}$ APC, T-bet PE, and Gata3 AF488 (eBiosciences, Vienna, Austria)) for the TF staining and Foxp3 Staining Buffer Set (eBiosciences) for the intracellular staining protocol. We used CD33 PE, CD11b FITC, HLA-DR PE-Cy5, and CD14 PE-Cy7 (eBiosciences) antibodies for MDSC staining. MDSCs were defined as $\mathrm{CD}_{3} 3^{+}, \mathrm{CD}_{11} \mathrm{~b}^{+}, \mathrm{CD} 14^{+}$, and HLA $\mathrm{DR}^{\text {low/neg }}$ cells. 
TABle 1: Demographic and clinical characteristics of patients with chronic hepatitis C.

\begin{tabular}{lc}
\hline Parameters & \\
\hline Age (years; range)* & $44(25-68)$ \\
Male sex, total number (\%) & $20(60.6)$ \\
HCV RNA (IU/mL) & 2150000 \\
Genotype 1b & $27(81.8)$ \\
\hline
\end{tabular}

${ }^{*}$ Data are expressed as median; IU, international units.

The expression of activation markers on $\mathrm{CD} 8^{+} \mathrm{T}$ cells was measured immediately after blood sampling with the $\mathrm{BD}$ Multitest ${ }^{\mathrm{TM}}$ CD8/CD38/CD3/HLA-DR (BD Biosciences, San Jose, CA, USA) according to the original protocol using a BD FACSCanto $^{\mathrm{TM}}$ II in Prague and a Navios ${ }^{\mathrm{TM}}$ (Beckman Coulter, Brea, CA, USA) in Hradec Králové. CD38 ${ }^{+}$, HLA$\mathrm{DR}^{+}$, and $\mathrm{CD} 38^{+} \mathrm{HLA}-\mathrm{DR}^{+}$cells were gated as a percentage of $\mathrm{CD}^{+} \mathrm{T}$ lymphocytes. The data were evaluated using FlowJo software ${ }^{\mathrm{TM}}$ (Treestar Inc., Ashland, OR, USA).

The detection of HCV RNA in the serum was performed as follows. First, nucleic acid was extracted using the Prepito (PerkinElmer, Waltham, MA, USA) automated magnetic separation system and Chemagic Preito NA Body Fluid kit ${ }^{\mathrm{TM}}$ (Chemagen, Baesweiler, Germany). Subsequently, the HCV RNA was quantitated using an EliGene HCV LC CE ${ }^{\mathrm{TM}}$ kit (Elisabeth Pharmacon, Brno, Czech Republic). The RT-PCR 2.0 for gen- $\mathrm{C}^{\mathrm{TM}}$ and GEN-C 2.0 Hepatitis C Subtyping ${ }^{\mathrm{TM}}$ kits (both from Nuclear Laser Medicine S.r.l., Naples, Italy) were used to determine HCV genotypes and subtypes. In addition, the detection of anti-HCV antibodies was performed by 3rd-generation enzymatic immunoassay with chemiluminiscent detection on the Architect i2000 analyser (Abbott, Abbott Park, IL, USA).

2.3. Statistical Analysis. All statistical analyses were conducted by a certified biostatistician in R software (R Core Team 2019, Vienna, Austria). To compare individual groups of subjects among themselves in a pairwise manner, we applied two-way ANOVA followed by post hoc Tukey's honest significant difference test. Correlations among individual parameters were evaluated using Pearson's product moment correlation coefficient. In all cases, only a $p$ value $<$ 0.05 was assumed to be significant.

\section{Results}

Expression of the lineage-defining TFs in $\mathrm{CD} 4^{+} \mathrm{T}$ cells was significantly modulated by chronic HCV infection. Namely, the percentages of $\mathrm{CD}^{+}{ }^{+} \mathrm{T}$ cells expressing Ror $\gamma \mathrm{t}$ and Gata3 were lower, and the percentage of Foxp3-expressing $\mathrm{CD}^{+}$ T cells was higher in the patients with $\mathrm{CHC}$ in comparison to those in persons with spontaneous HCV clearance and healthy controls (Table 2). A representative histogram showing the differences in the Ror $\gamma t$ expression level among the study cohorts is presented in Figure 1. Next, the patients with $\mathrm{CHC}$ had the highest ratios of T-bet ${ }^{+}$to $\mathrm{Gata}^{+} \mathrm{CD}^{+}$ $\mathrm{T}$ cells and Foxp $3^{+}$to Ror $\mathrm{t}^{+} \mathrm{CD} 4^{+} \mathrm{T}$ cells (Table 2). The percentages of $\mathrm{CD}^{+}{ }^{+} \mathrm{T}$ cells expressing Gata3 and Ror $\gamma \mathrm{t}$ positively correlated $(r=0.592, p<0.001)$; similarly, the percentages of $\mathrm{T}$-bet ${ }^{+} \mathrm{CD} 4^{+} \mathrm{T}$ cells and $\mathrm{CD} 38^{+} / \mathrm{HL}^{-} \mathrm{DR}^{+}$ $\mathrm{CD} 8^{+} \mathrm{T}$ cells demonstrated a positive correlation $(r=0.389$, $p=0.033)$. In addition, the percentage of circulating MDSCs correlated negatively with the percentage of $\mathrm{CD} 38^{+}$/ HLA-DR ${ }^{+} \mathrm{CD}^{+} \mathrm{T}$ cells $(r=-0.441, p=0.015)$.

\section{Discussion}

In this study, we evaluated the circulating levels of $\mathrm{CD} 4^{+} \mathrm{T}$ subsets (Th1, Th2, Th17, and Tregs), activated $\mathrm{CD}^{+} \mathrm{T}$ cells, and MDSCs in the peripheral blood of patients with $\mathrm{CHC}$, persons with spontaneous HCV clearance, and healthy controls.

The decreased percentage of $\mathrm{CD} 4^{+} \mathrm{Th} 17$ cells observed in patients with $\mathrm{CHC}$ probably reflects a shift to more immunosuppressive response with Treg cells and MDSCs, a phenomenon that may be responsible for the persistence of $\mathrm{HCV}$ infection. It is well known that $\mathrm{CD}^{+} \mathrm{Th} 17$ cells have also been shown to play a role in viral infections. It has been speculated that the decrease in Th17 $\mathrm{CD} 4^{+} \mathrm{T}$ cells observed in the blood of HIV-positive patients is associated with the loss of mucosal barrier integrity [13]. Chronic HCV infection also modulates Th17 $\mathrm{CD} 4{ }^{+} \mathrm{T}$ cell responses, which have beneficial and detrimental effects. Although the percentage of HCV-specific Th17 cells in the blood correlated positively with the severity of liver fibrosis and intrahepatic inflammation, a strong Th17 response may also lead to clearance of $\mathrm{HCV}$ infection [14]. Interestingly, the trend of the highest percentage of Ror $\gamma \mathrm{t}$-expressing $\mathrm{CD} 4^{+} \mathrm{T}$ cells was observed in the study subjects with spontaneous HCV clearance, which, together with the finding of the decreased percentage of $\mathrm{CD} 4^{+} \mathrm{T}$ cells expressing Ror $\gamma \mathrm{t}$ in viremic patients (Figure 2), supports the suggested role of the Th17 response in HCV clearance. This phenomenon may have a genetic background because a study of two single-nucleotide polymorphisms located in the RORC gene demonstrated that the most common Th17-related RORC gene haplotype among the study population of Chinese Han females was associated with spontaneous HCV clearance [15]. On the other hand, intense Ror $\gamma \mathrm{t}$ expression in $\mathrm{CD} 4^{+} \mathrm{T}$ cells leading to the development of a robust Th17 response may aggravate inflammation, causing detrimental effects of CHC. It was suggested that this intense inflammation associated with autoimmune complications of $\mathrm{CHC}$ is elicited by HCV core antigen, which strongly augmented Ror $\gamma \mathrm{t}$ expression in naive $\mathrm{CD}^{+} \mathrm{T}$ cells in in vitro experiments [16]. This proinflammatory reaction is probably counterbalanced by Tregs, which can be reflected by the high ratio of Tregs to Th17 cells and increased frequencies of circulating Tregs observed in patients with $\mathrm{CHC}[6,17]$.

The finding of the decreased percentage of Gata3expressing $\mathrm{CD}^{+}{ }^{+} \mathrm{T}$ cells in the blood of patients with $\mathrm{CHC}$ is surprising because persistent viral infections, including chronic HCV infection, are associated with a shift to a Th2 response and a simultaneous loss of Th1 $\mathrm{CD} 4^{+} \mathrm{T}$ cells [18]. Because Gata3 is able to induce the Th2 phenotype, its decreased expression may correlate with reduced Th2 responses. It is worth noting that the TF T-bet, which is responsible for Th1 polarization, directly modulates Gata3 
TABLE 2: Comparison of the expression levels of transcriptional factors and the percentage of myeloid-derived suppressor cells among the study groups.

\begin{tabular}{|c|c|c|c|}
\hline Parameters & $\mathrm{CHC}$ & SC & $\mathrm{HC}$ \\
\hline T-bet $^{+} \mathrm{CD}^{+} \mathrm{T}$ cells $(\%)$ & $15.95(15.54)$ & $12.3(12.86)$ & $14.9(15.86)$ \\
\hline $\mathrm{Gata}^{+} \mathrm{CD}^{+}{ }^{+} \mathrm{T}$ cells $(\%)$ & $56.05(42.78)$ & $68.6(18.35)^{* *}$ & $65.4(14.7)^{*}$ \\
\hline Ror $\gamma \mathrm{t}^{+} \mathrm{CD} 4^{+} \mathrm{T}$ cells $(\%)$ & $83.30(34.33)$ & $96.6(1.8)^{* *}$ & $93.6(10.7)^{* *}$ \\
\hline Foxp $^{+} \mathrm{CD}^{+} \mathrm{T}$ cells $(\%)$ & $5.33(1.9)$ & $4.75(1.08)^{*}$ & $4.38(1.16)^{* *}$ \\
\hline T-bet/Gata3 & $0.293(0.444)$ & $0.170(0.181)^{*}$ & $0.182(0.254)^{*}$ \\
\hline Foxp3/Ror $\gamma t$ & $0.077(0.072)$ & $0.049(0.009)^{* *}$ & $0.048(0.015)^{* *}$ \\
\hline MDSC (\%) & $0.86(0.8)$ & $0.66(0.77)$ & $0.91(0.99)$ \\
\hline
\end{tabular}

Data are in medians (IQR); CHC, chronic hepatitis C; SC, spontaneous viral clearance; HC, healthy controls; ${ }^{* *} p<0.01$ vs. patients; ${ }^{*} p<0.05$ vs. patients; MDSC, myeloid-derived suppressor cells.

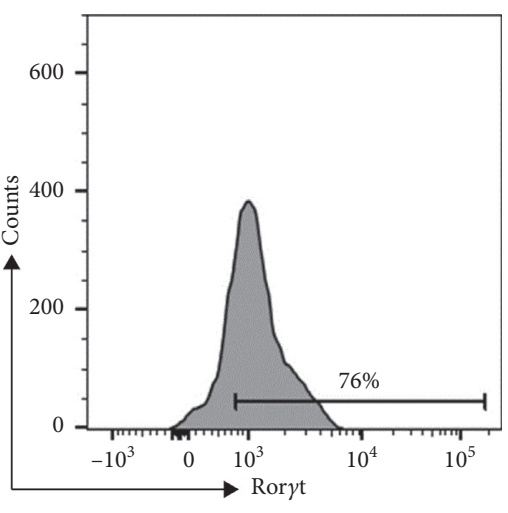

(a)

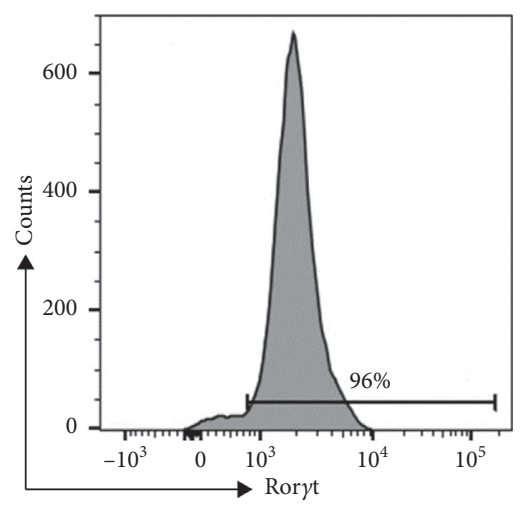

(b)

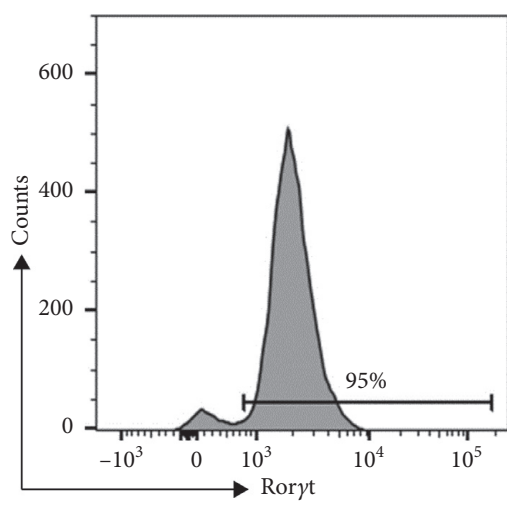

(c)

FIGURE 1: Representative histogram of Ror $\gamma$ t expression in patients with chronic hepatitis C (a), persons with spontaneous viral clearance (b), and healthy controls (c).

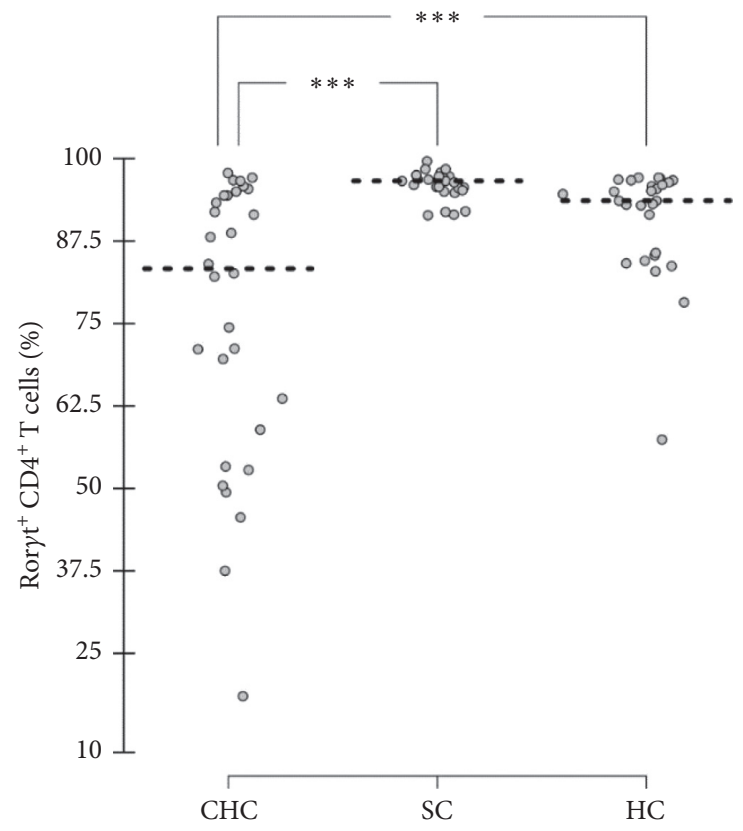

Figure 2: Percentage of $\mathrm{CD}^{+}$T cells expressing Ror $\gamma \mathrm{t}$ in patients with chronic hepatitis $\mathrm{C}(\mathrm{CHC})$, persons with spontaneous viral clearance (SC), and healthy controls (HC). ${ }^{* * *} p<0.001$. 
expression [19]. Moreover, FoxP3 and Gata3 play a competitive role, similar to T-bet and Gata3 [20]. This notion can be supported by our findings of a high ratio of T-bet- and Gata3-expressing $\mathrm{CD}^{+} \mathrm{T}$ cells and by well-documented increases in the frequencies of circulating Tregs and Foxp3 expression in PBMCs in patients with $\mathrm{CHC}[6,21]$. Altogether, these data indicate enhanced polarization of $\mathrm{CD} 4^{+}$ T cells toward Th1 and Treg phenotypes associated with a reduced Th2 response during persistent $\mathrm{HCV}$ infection. Despite the higher ratio of T-bet ${ }^{+} / \mathrm{Gata}^{+} \mathrm{CD}^{+} \mathrm{T}$ cells in the chronic HC patients, the frequency of T-bet-expressing $\mathrm{CD}^{+} \mathrm{T}$ cells did not differ among the study groups, indicating a reduced capacity for Th1 polarization. Since a strong Th1 response and activation of cytolytic $\mathrm{CD}^{+} \mathrm{T}$ cells are necessary for the clearance of $\mathrm{HCV}$, reduced Th1 polarization can be an important mechanism leading to CHC.

Several correlations were observed among the study parameters. First, the positive correlation between the percentages of Ror $\gamma \mathrm{t}$ - and Gata3-expressing $\mathrm{CD} 4^{+} \mathrm{T}$ cells indicates their functional interplay. At low levels, Gata3 contributes to the development of Ror $\gamma \mathrm{t}$-expressing $\mathrm{CD} 4^{+}$ T cells; however, the role of Gata 3 in Th1 or Th17 cells is still unclear [22]. Next, the observed positive correlation between T-bet-expressing $\mathrm{CD}^{+} \mathrm{T}$ cells and the activated $\mathrm{CD}^{+}$ T cells, which express CD38 and HLA-DR molecules, reflects a direct connection between the Th1 response and cytotoxic immunity. It is well known that Th 1 cells produce IFN- $\gamma$, inducing cytotoxic $\mathrm{T}$ cells that are crucial for the control of HCV replication and lysis of infected cells [23]. In addition to T-cell regulatory interactions, a negative correlation between monocytic MDSCs and activated $\mathrm{CD}^{+} \mathrm{T}$ cells found in the study subjects with CHC may reflect suppression of T-cell-mediated immunity by MDSCs. This notion is supported by the results of a study that demonstrated high levels of phosphorylated signal transducer and activator of transcription 3 and IL-10 in MDSCs isolated from patients with $\mathrm{CHC}$ [24]. When these MDSCs were depleted from isolated PBMCs, it led to in vitro restoration of T-cell-mediated immunity and significantly increased IFN- $\gamma$ production. Thus, our findings likely suggest the immunosuppressive potential of HCV-induced MDSCs.

This study has several limitations. First, we did not evaluate the phenotypes of circulating $\mathrm{CD} 4^{+} \mathrm{T}$ cells using analysis of intracellular cytokines. Nevertheless, our findings are consistent with previous studies. Second, we did not provide detailed information on persons with spontaneous viral clearance, including when and how these subjects contracted HCV infection. The reason is that many of these subjects were drug addicts lost on follow-up, and retrieving additional clinical data from this cohort was impossible. Third, the study was originally designed as a longitudinal study of effects of IFN-based therapies of $\mathrm{CHC}$ on the frequencies of TF expression in $\mathrm{CD}^{+}{ }^{+} \mathrm{T}$ cells for which the samples size was calculated. Therefore, the cohorts of $\mathrm{CHC}$ patients and persons with spontaneous viral clearance are relatively small. On the other hand, the study design enabled us to evaluate TFs profiles of $\mathrm{CD}^{+} \mathrm{T}$ cells that may play a role in the transition from acute to chronic viral infection.

\section{Conclusions}

The observed modulation of lineage-defining TFs in $\mathrm{CD} 4^{+}$ $\mathrm{T}$ cells indicates downregulation of proinflammatory responses as an important mechanism leading to chronic HCV infection. Nevertheless, our data also suggest a protective role of the Th17 response, which can be utilized in the development of a preventive HCV vaccine.

\section{Data Availability}

All data generated or analyzed during this study are included in this published article.

\section{Conflicts of Interest}

The authors declare that there are no conflicts of interest.

\section{Acknowledgments}

The authors thank Dr. David A. Lawrence (Wadsworth Center, NYS DOH, Albany, USA) for critical review of the data and proofreading of the manuscript. This work was supported by the Internal Grant Agency of the Ministry of Health of the Czech Republic grant NT 14072-3/2013 and the Charles University Project PROGRES Q26/LF1.

\section{References}

[1] H. Leblebicioglu, J. E. Arends, R. Ozaras et al., "Availability of hepatitis C diagnostics and therapeutics in European and Eurasia countries," Antiviral Research, vol. 150, pp. 9-14, 2018.

[2] G. Montalto, M. Cervello, L. Giannitrapani, F. Dantona, A. Terranova, and L. A. Castagnetta, "Epidemiology, risk factors, and natural history of hepatocellular carcinoma," Annals of the New York Academy of Sciences, vol. 963, pp. 13-20, 2002.

[3] J. J. Jost, B. Tempalski, T. Vera, M. J. Akiyama, A. P. Mangalonzo, and A. H. Litwin, "Gaps in HCV knowledge and risk behaviors among young suburban people who inject drugs," Int J Environ Res Public Health, vol. 16, 2019.

[4] D. I. Chigbu, R. Loonawat, M. Sehgal, D. Patel, and P. Jain, "Hepatitis C virus infection: host-virus interaction and mechanisms of viral persistence," Cells, vol. 8, no. 4, 2019.

[5] M. Irshad, D. S. Mankotia, and K. Irshad, "An insight into the diagnosis and pathogenesis of hepatitis C virus infection," World Journal of Gastroenterology, vol. 19, no. 44, pp. 78967909, 2013.

[6] P. Chalupa, A. Davidová, O. Beran et al., "Effect of antiviral treatment of chronic hepatitis $\mathrm{C}$ on the frequency of regulatory T cells, T-cell activation, and serum levels of TGF-beta," APMIS, vol. 124, no. 8, pp. 711-718, 2016.

[7] D. $\mathrm{Xu}$, J. Fu, L. Jin et al., "Circulating and liver resident $\mathrm{CD} 4+\mathrm{CD} 25+$ regulatory T cells actively influence the antiviral immune response and disease progression in patients with hepatitis B," The Journal of Immunology, vol. 177, no. 1, pp. 739-747, 2006.

[8] H. Kared, T. Fabre, N. Bédard, J. Bruneau, and N. H. Shoukry, "Galectin-9 and IL-21 mediate cross-regulation between Th17 and Treg cells during acute hepatitis C," PLoS Pathogens, vol. 9, Article ID e1003422, 2013. 
[9] S. Nakayamada, H. Takahashi, Y. Kanno, and J. J. O’Shea, "Helper T cell diversity and plasticity," Current Opinion in Immunology, vol. 24, no. 3, pp. 297-302, 2012.

[10] J. J. O'Shea and W. E. Paul, "Mechanisms underlying lineage commitment and plasticity of helper CD4+ T cells," Science, vol. 327, pp. 1098-1102, 2010.

[11] A. Crawford, J. M. Angelosanto, C. Kao et al., "Molecular and transcriptional basis of $\mathrm{CD} 4+\mathrm{T}$ cell dysfunction during chronic infection," Immunity, vol. 40, no. 2, pp. 289-302, 2014.

[12] V. Telatin, F. Nicoli, C. Frasson et al., "In chronic hepatitis C infection, myeloid-derived suppressor cell accumulation and $\mathrm{T}$ cell dysfunctions revert partially and late after successful direct-acting antiviral treatment," Front Cell Infect Microbiol, vol. 9, p. 190, 2019.

[13] B. Kanwar, D. Favre, and J. M. McCune, "Th17 and regulatory T cells: implications for AIDS pathogenesis," Current Opinion in HIV and AIDS, vol. 5, no. 2, pp. 151-157, 2010.

[14] P. Bălănescu, A. Lădaru, T. Voiosu, A. Nicolau, M. Ene, and E. Bălănescu, "Th17 and IL-17 immunity in chronic hepatitis C infection," Romanian Journal of Internal Medicine, vol. 50, pp. 13-18, 2012.

[15] Z. Xie, Y. Li, L. Long, H. Liang, W. Cai, and T. Shen, "Polymorphisms in the Th17 cell-related RORC gene are associated with spontaneous clearance of HCV in Chinese women," BMC Infectious Diseases, vol. 18, p. 254, 2018.

[16] Y. Kondo, M. Ninomiya, O. Kimura, K. Machida, R. Funayama, and T. Nagashima, "HCV infection enhances Th17 commitment, which could affect the pathogenesis of autoimmune diseases," PLoS One, vol. 9, Article ID e98521, 2014.

[17] C. Hao, Y. Zhou, Y. He et al., "Imbalance of regulatory T cells and T helper type 17 cells in patients with chronic hepatitis $\mathrm{C}$," Immunology, vol. 143, no. 4, pp. 531-538, 2014.

[18] L. M. Snell, I. Osokine, D. H. Yamada, J. R. De la Fuente, H. J. Elsaesser, and D. G. Brooks, "Overcoming CD4 Th1 cell fate restrictions to sustain antiviral CD8 T cells and control persistent virus infection," Cell Reports, vol. 16, no. 12, pp. 3286-3296, 2016.

[19] T. Usui, J. C. Preiss, Y. Kanno et al., "T-bet regulates Th1 responses through essential effects on GATA-3 function rather than on IFNG gene acetylation and transcription," Journal of Experimental Medicine, vol. 203, no. 3, pp. 755-766, 2006.

[20] P.-Y. Mantel, H. Kuipers, O. Boyman et al., "GATA3-Driven Th2 responses inhibit TGF- $\beta 1$-induced FOXP3 expression and the formation of regulatory T cells," PLoS Biology, vol. 5, no. 12, p. e329, 2007.

[21] A. Dolganiuc, E. Paek, K. Kodys, J. Thomas, and G. Szabo, "Myeloid dendritic cells of patients with chronic HCV infection induce proliferation of regulatory $\mathrm{T}$ lymphocytes," Gastroenterology, vol. 135, no. 6, pp. 2119-2127, 2008.

[22] J. Zhu, "GATA3 regulates the development and functions of innate lymphoid cell subsets at multiple stages," Frontiers in Immunology, vol. 8, p. 1571, 2017.

[23] M. J. Koziel, "Cellular immune responses against hepatitis C virus," Clinical Infectious Diseases, vol. 41, no. 1, pp. S25-S31, 2005.

[24] J. P. Ren, J. Zhao, J. Dai et al., "Hepatitis C virus-induced myeloid-derived suppressor cells regulate T-cell differentiation and function via the signal transducer and activator of transcription 3 pathway," Immunology, vol. 148, no. 4, pp. 377-386, 2016. 